\title{
PENGARUH KEJUTAN SUHU PANAS DAN LAMA WAKTU SETELAH PEMBUAHAN TERHADAP DAYA TETAS DAN ABNORMALITAS LARVA IKAN NILA (Oreochromis niloticus)
}

\section{THE THERMAL TEMPERATURE SHOCK AND TIME AFTER FERTILIZATION IN HATCHING RATE AND ABNORMALITY OF NILE FISH (Oreochromis niloticus)}

\author{
Akhmad Taufiq Mukti, Herliana Arsianingtyas dan Sri Subekti \\ Fakultas Perikanan dan Kelautan Universitas Airlangga \\ Kampus C Mulyorejo - Surabaya, 60115 Telp. 031-5911451
}

\begin{abstract}
The chromosome manipulation in fish is one of the strategy that will be used to produce of the high generation and good quality in its genetics, as follow fast to grow, disease resistant, high survival, tolerate with environment exchange and easy to be cultured. One of manipulation chromosome the method in fish used thermal temperature shock. The aim of the study was to know the thermal temperature shock and the time after fertilization forward hatching rate and abnormality of nile fish larvae and also to know the thermal temperature shock and the time after fertilization that resulted the best hatching rate and abnormality in nile fish larvae. The method was Factorial Completed Randomized Design as experimental design. The treatment used temperatures shock were $40^{\circ} \mathrm{C}, 41^{\circ} \mathrm{C}$ and $42^{\circ} \mathrm{C}$ as long as 2,5 minutes, with the time of 80,85 and 90 minutes after fertilization, each treatment was four replications. The primary parameter was hatching rate and abnormality of nile fish larvae and the secondary parameter were fertilization and water quality. The result showed that the thermal temperature shock was significantly influenced to hatch rate and abnormality, but the time of shocking after fertilization and the interaction between them showed were not significantly influenced to hatch rate and abnormality. The highest of hatching rate and abnormality percentage was showed by the treatment with shocking $40^{\circ} \mathrm{C}$ was 90,77 percent and 2,60 percent.
\end{abstract}

Key words : nile fish, hatching rate, abnormality, heat temperature shock, time after fertilization

\section{Pendahuluan}

Budidaya ikan nila (Oreochromis niloticus) mempunyai prospek yang baik untuk dikembangkan di Indonesia, karena budidayanya dapat dilakukan di tambak, lahan bekas galian pasir atau penambangan dan karamba jaring apung (KJA) di perairan umum atau laut. Potensi ikan nila untuk di budidayakan cukup besar karena memiliki beberapa kelebihan, yaitu mudah berkembangbiak, pertumbuhan cepat, kandungan protein cukup tinggi, ukuran tubuh relatif besar, tahan terhadap penyakit, mudah beradaptasi dengan lingkungan, harga relatif murah dan mempunyai nilai gizi yang cukup tinggi sebagai sumber protein hewani. Ikan nila merupakan jenis ikan omnivora, artinya tidak memerlukan pakan yang khusus (Wardoyo, 2005). Akan tetapi, akhir-akhir ini terjadi penurunan produksi budidaya ikan nila yang diakibatkan rendahnya kualitas induk dan benih yang dihasilkan oleh pembudidaya. Salah satu penyebabnya adalah pengelolaan induk yang tidak tepat dan tingginya inbreeding dalam usaha pembenihan ikan nila (Mukti dkk., 2001).

Manipulasi kromosom pada ikan merupakan salah satu strategi yang diharapkan dapat digunakan untuk memproduksi keturunan dengan sifat unggul dan kualitas genetiknya baik, seperti memiliki pertumbuhan relatif cepat, tahan terhadap penyakit, kelangsungan hidup tinggi, toleran terhadap perubahan lingkungan (suhu, $\mathrm{pH}$, oksigen terlarut, salinitas) dan mudah dibudidayakan (Mukti, 1999). Tetraploidisasi merupakan salah satu metode manipulasi kromosom pada ikan yang menghasilkan ikan dengan jumlah kromosom 4n (tetraploid). Metode tetraploid dapat dilakukan seperti halnya metode ginogenesis (gynogenesis mitosis), yaitu perlakuan kejutan pada telur dilakukan setelah terjadi peloncatan polar body II (Mukti dkk., 2007).

Berdasarkan penelitian sebelumnya, ikan nila tetraploid dapat diproduksi dengan berbagai teknik, yaitu kejutan suhu panas, kejutan suhu dingin, penggunaan tekanan tinggi atau radiasi ultraviolet. Di antara berbagai metode tersebut, teknik yang paling murah dan mudah dilakukan untuk menghasilkan ikan tetraploid adalah teknik kejutan suhu panas (Herbst, 2002; Shelton 2006). Chourrout (1986) dalam Risnandar (2001) menyatakan, kejutan suhu panas mempunyai kepraktisan, yaitu dapat dilakukan dalam jumlah besar dan memerlukan waktu yang lebih singkat daripada kejutan suhu dingin.

Shelton (2006) dan Suzu et al. (2006) menyebutkan, waktu optimal dilakukan kejutan 
pada zigot adalah ketika sel mencapai tahap prometafase akhir atau saat metafase. Namun kesulitannya adalah belum ditemukan prosedur yang tepat untuk menghasilkan ikan nila tetraploid, terutama dalam variabel umur telur setelah pembuahan, lama kejutan dan tingkat suhu kejutan. Hal ini dibuktikan dari banyaknya hasil penelitian yang prosedurnya berbeda dan menghasilkan simpulan yang berbeda pula. Herbst (2002) menyebutkan bahwa melakukan kejutan suhu panas pada waktu 24 menit dengan suhu 42,8oC akan menghasilkan ikan tetraploid sebesar sepuluh persen. Namun, hingga saat ini belum diperoleh induk nila yang benar-benar tetraploid.

Penelitian ini bertujuan untuk Mengetahui pengaruh kejutan suhu panas dan lama waktu setelah pembuahan terhadap daya tetas dan abnormalitas larva ikan nila serta mengetahui kejutan suhu panas dan lama waktu setelah pembuahan yang menghasilkan persentase daya tetas dan abnormalitas tertinggi pada larva ikan nila.

Penelitian ini diharapkan dapat memberikan informasi mengenai kejutan suhu panas dan lama waktu setelah pembuahan untuk menghasilkan daya tetas dan abnormalitas tertinggi larva ikan nila. Selain itu penelitian tersebut bertujuan untuk menghasilkan ikan nila tetraploid.

\section{Materi dan Metode Penelitian}

Tempat dan waktu

Penelitian ini dilaksanakan di Balai Pengembangan Budidaya Air Tawar (BPBAT) Umbulan, Pasuruan pada bulan September Oktober 2008

Alat penelitian

Alat yang digunakan dalam penelitian ini adalah kolam pemeliharaan, kolam pemijahan, perangkat penetasan telur, pompa elektrik, gelas berkaki volume $300 \mathrm{ml}$, waring hijau, sedotan, karet gelang, cawan petri, bulu ayam, mangkok bertutup, pengatur aerasi, saringan santan, botol air mineral 1,5 liter, jaring segitiga, termometer, heater, kotak styrofoam dan alat tulis.

Bahan penelitian

Bahan yang digunakan dalam penelitian ini adalah induk ikan nila yang terdiri dari 20 betina dan 10 jantan berasal dari minimal tiga strain, pakan induk berupa pellet (kadar protein 35 persen), pakan benih berupa cacing Tubifex spp, pakan benih berupa ukuran remah (kadar protein 35
- 40 persen), Artemia, obat anti jamur (Methylen Blue), larutan fisiologis pengencer sperma $(\mathrm{NaCl}$ $0,9 \mathrm{ml}$ ) dan garam krosok (garam yang belum diolah).

Rancangan penelitian

Rancangan percobaan yang digunakan dalam penelitian ini adalah Rancangan Acak Lengkap Faktorial, karena terdapat dua sumber keragaman (Kusriningrum,1990). Dua keragaman tersebut, yaitu kejutan suhu dan umur telur setelah pembuahan. Kejutan suhu panas yang digunakan, yaitu $40^{\circ} \mathrm{C}, 41^{\circ} \mathrm{C}$ dan $42^{\circ} \mathrm{C}$. Lama waktu setelah pembuahan yang digunakan yaitu 80 menit setelah pembuahan, 85 menit setelah pembuahan dan 90 menit setelah pembuahan. Masing-masing kombinasi diulang empat kali, sehingga diperoleh 36 satuan percobaan. Perlakuan tanpa kejutan suhu dilakukan sebagai pembanding dan diulang empat kali, sehingga satuan percobaan seluruhnya berjumlah 48 satuan percobaan.

Pematangan gonad induk ikan nila

Induk ikan nila jantan dan betina dipelihara secara terpisah dalam kolam pemeliharaan. Induk ikan tersebut diberi pakan berupa pakan buatan bentuk pellet komersial, frekuensi pemberian pakan dilakukan sebanyak tiga kali sehari, yaitu pagi, siang dan sore hari.

Seleksi induk ikan nila betina matang gonad

Pengamatan kematangan gonad dilakukan secara teratur dan terus menerus. Ikan nila betina dan jantan yang siap memijah dicirikan dengan genital papilanya menonjol secara jelas dan berwarna merah.

Pemijahan induk ikan nila

Induk ikan nila betina dan jantan yang siap memijah dipindahkan ke kolam pemijahan. Pemijahan berlangsung berkisar antara $2-3$ jam pada siang hari. Pemijahan terjadi pada pukul 14.00 - 15.00 WIB. Pemijahan biasanya diawali dengan ikan nila jantan membersihkan dasar kolam dengan mulutnya, seperti sedang mempersiapkan sarang pemijahan. Kemudian, ikan nila betina mengeluarkan telur sedikit demi sedikit di dasar kolam. Setelah ikan nila betina mengeluarkan sebagian telurnya, kemudian ikan nila jantan mengeluarkan sperma di dekat telur tersebut. Setelah itu, ikan nila betina segera mengambil telur dan sperma dengan mulutnya. 
Fertilisasi buatan dan inkubasi telur ikan nila

Proses pemijahan berlangsung beberapa kali, setelah proses pemijahan berakhir, induk ikan nila betina dan jantan dipisahkan. Telur dan sperma ikan nila diperoleh dengan teknik stripping, hal tersebut dilakukan setelah induk ikan nila betina mengeluarkan telur untuk pertama kalinya. Telur yang didapat selanjutnya dimasukkan ke dalam mangkok bertutup. Setelah mendapatkan sperma sebanyak $1 \mathrm{ml}$, sperma diencerkan dengan $\mathrm{NaCl}$ sebanyak $9 \mathrm{ml}$. Kemudian sperma dicampurkan dengan telur selama satu menit dengan menggunakan bulu ayam. Telur yang telah terbuahi dicuci menggunakan air bersih dan segera dimasukkan ke dalam gelas berkaki. Masingmasing gelas berisi 150 telur dan diberi aerasi. Gelas - gelas tersebut diletakkan di perangkat aerasi yang berada dalam bak inkubasi. Media air inkubasi bersuhu konstan, yaitu $28^{\circ} \mathrm{C}$ dengan memberi Methylen blue sebagai pencegah jamur. Penghitungan jumlah telur terfertilisasi dan jumlah telur tidak terfertilisasi dilakukan lebih kurang delapan jam setelah proses fertilisasi. Telur yang tidak terfertilisasi berwarna putih keruh.

\section{Kejutan suhu panas}

Kejutan suhu panas dilakukan dalam kotak styrofoam yang telah berisi air dengan suhu $40^{\circ} \mathrm{C}, 41^{\circ} \mathrm{C}$ dan $42^{\circ} \mathrm{C}$ selama 2,5 menit. Lama waktu setelah pembuahan yang digunakan, yaitu 80 menit setelah pembuahan, 85 menit setelah pembuahan dan 90 menit setelah pembuahan. Telur yang telah diberi kejutan suhu panas, ditetaskan di dalam gelas yang berisi air dengan suhu konstan $28^{\circ} \mathrm{C}$ dan diberi aerasi. Telur akan menetas dalam waktu empat hari. Setelah berumur sepuluh hari, larva ikan nila diberi pakan berupa Artemia selama satu minggu. Frekuensi pemberian Artemia sebanyak tiga kali sehari, yaitu pagi, siang dan sore hari. Selanjutnya, larva ikan nila diberi pakan berupa cacing darah selama satu minggu dengan pemberian tiga kali sehari.

\section{Daya tetas}

Perhitungan yang dilakukan untuk mengetahui besarnya daya tetas seperti yang dikemukakan oleh Mukti dkk. (2007), yaitu :

HR (\%) : $\frac{\text { Jumlah telur menetas normal }}{\text { Jumlah telur menetas normal, cacat dan mati }} \times 100 \%$

Keterangan : $\mathrm{HR}=$ hatching rate (daya tetas)
Abnormalitas

Pengamatan abnormalitas dalam penelitian ini meliputi bentuk kepala, bentuk tubuh dan bentuk ekor. Perhitungan yang dilakukan untuk mengetahui besarnya abnormalitas seperti yang dikemukakan oleh Wirawan (2005), yaitu :

$$
\text { Abnormalitas : } \frac{\text { Jumlah larva abnormal }}{\text { Jumlah larva normal }} \times 100 \%
$$

Daya fertilitas

Perhitungan yang dilakukan untuk mengetahui besarnya daya fertilitas seperti yang dikemukakan oleh Yustina dan Darmawati (2003), yaitu :

$$
\text { FR (\%) : } \frac{\text { Jumlah telur yang dibuahi }}{\text { Jumlah telur seluruhnya }} \times 100 \%
$$

Keterangan $: \mathrm{FR}=$ fertilization rate (daya fertilitas)

Parameter penunjang yang diukur, yaitu pengukuran kualitas air meliputi suhu, $\mathrm{pH}$ dan oksigen terlarut yang dilakukan setiap seminggu sekali pada pagi dan sore hari yaitu pukul 08.00 WIB dan 16.00 WIB.

\section{Analisis data}

Data dianalisis secara statistik dengan ANOVA untuk mengetahui ada tidaknya perbedaan dari perlakuan yang diberikan. Jika dari analisis ragam diketahui bahwa perlakuan menunjukkan pengaruh yang berbeda nyata atau berbeda sangat nyata, maka dilakukan Uji Jarak Berganda Duncan untuk membandingkan perlakuan yang menghasilkan hasil terbaik (Kusriningrum, 1990).

\section{Hasil dan Pembahasan}

Daya tetas larva ikan nila

Daya tetas merupakan perbandingan antara jumlah telur menetas normal dengan jumlah telur menetas normal, cacat dan mati dikalikan dengan $100 \%$. Data rata - rata persentase daya tetas larva ikan nila terdapat pada Tabel 1.

Hasil penghitungan Anova menunjukkan bahwa kejutan suhu berpengaruh nyata $(\mathrm{p}<0,05)$ terhadap daya tetas larva ikan nila. Lama waktu setelah pembuahan dan interaksi antara kejutan suhu dan lama waktu setelah pembuahan tidak berpengaruh nyata $(p>0,05)$ terhadap daya tetas larva ikan nila. Selanjutnya, untuk mengetahui tingkat perbedaan pada tiap perlakuan atau untuk mengetahui perlakuan mana yang memberikan hasil yang terbaik, maka dilakukan uji lanjutan dengan menggunakan Uji Jarak Berganda Duncan. 
Hasil uji jarak berganda duncan menunjukkan bahwa rata - rata persentase daya tetas larva ikan nila pada perlakuan $\mathrm{C}\left(41^{\circ} \mathrm{C}\right)$ dan $\mathrm{D}$ $\left(42^{\circ} \mathrm{C}\right)$ tidak berbeda nyata $(\mathrm{p}>0,05)$ dengan perlakuan $\mathrm{B}\left(40^{\circ} \mathrm{C}\right)$, tetapi berbeda nyata dengan perlakuan $\mathrm{A}\left(28^{\circ} \mathrm{C}\right)$ (Tabel 1).

Tabel 1. Data rata-rata persentase daya tetas larva ikan nila tiap perlakuan suhu dan lama waktu setelah pembuahan

\begin{tabular}{|c|c|c|c|c|}
\hline \multirow{2}{*}{ Suhu } & \multicolumn{3}{|c|}{$\begin{array}{c}\text { Lama Waktu } \\
\text { setelah Pembuahan }\end{array}$} & \multirow{2}{*}{$\begin{array}{c}\text { Rata- } \\
\text { rata }\end{array}$} \\
\cline { 2 - 4 } & 80 menit & 85 menit & 90 menit & \\
\hline A $\left(28^{\circ} \mathrm{C}\right)$ & 92,17 & 92,17 & 92,17 & $92,17^{\mathrm{b}}$ \\
(kontrol) & & & & \\
$\mathrm{B}\left(40^{\circ} \mathrm{C}\right)$ & 90,50 & 90,66 & 91,16 & $90,77^{\mathrm{ab}}$ \\
$\mathrm{C}\left(41^{\circ} \mathrm{C}\right)$ & 89,16 & 85,50 & 90,49 & $88,38^{\mathrm{a}}$ \\
$\mathrm{D}\left(42^{\circ} \mathrm{C}\right)$ & 88,83 & 87,16 & 86,99 & $87,51^{\mathrm{a}}$ \\
\hline Rerata & 90,16 & 88,87 & 90,20 & \multicolumn{3}{|c}{} \\
\hline
\end{tabular}

Keterangan : superskrip yang berbeda pada kolom yang sama menunjukkan hasil yang berbeda nyata $(\mathrm{p}>0,05)$

Abnormalitas larva ikan nila

Abnormalitas larva ikan nila dilakukan dengan mengamati keadaan bentuk tubuh larva ikan nila. Data rata - rata persentase abnormalitas larva ikan nila terdapat pada Tabel 2.

Tabel 2. Data rata-rata persentase abnormalitas larva ikan nila tiap perlakuan suhu dan lama waktu setelah pembuahan.

\begin{tabular}{|c|c|c|c|c|}
\hline \multirow{2}{*}{ Suhu } & \multicolumn{3}{|c|}{ Lama Waktu } & \multirow{2}{*}{$\begin{array}{c}\text { setelah Pembuahan } \\
\text { Rata- } \\
\text { rata }\end{array}$} \\
\cline { 2 - 5 } & 80 menit & 85 menit & 90 menit & \\
\hline $\mathrm{A}\left(28^{\circ} \mathrm{C}\right)$ & 0 & 0 & 0 & $0^{\mathrm{c}}$ \\
$($ kontrol $)$ & & & & \\
$\mathrm{B}\left(40^{\circ} \mathrm{C}\right)$ & 2,44 & 2,85 & 2,52 & $2,60^{\mathrm{a}}$ \\
$\mathrm{C}\left(41^{\circ} \mathrm{C}\right)$ & 1,93 & 1,58 & 2,18 & $1,90^{\mathrm{b}}$ \\
$\mathrm{D}\left(42^{\circ} \mathrm{C}\right)$ & 2,46 & 2,59 & 2,62 & $2,56^{\mathrm{a}}$ \\
\hline Rerata & 1,71 & 1,76 & 1,83 & \multicolumn{1}{|c}{} \\
\hline
\end{tabular}

Keterangan : superskrip yang berbeda pada kolom yang sama menunjukkan hasil yang berbeda nyata $(\mathrm{p}<0,05)$

Hasil penghitungan Anova menunjukkan bahwa kejutan suhu berpengaruh nyata $(\mathrm{p}<0,05)$ terhadap abnormalitas larva ikan nila. Lama waktu setelah pembuahan dan interaksi antara kejutan suhu dan lama waktu setelah pembuahan tidak berpengaruh nyata $(p>0,05)$ terhadap abnormalitas larva ikan nila. Hasil tersebut kemudian dilanjutkan dengan Uji Jarak Berganda Duncan untuk mengetahui perlakuan mana yang memberikan hasil terbaik terhadap abnormalitas larva ikan nila.

Hasil Uji Jarak Berganda Duncan menunjukkan bahwa rata - rata persentase abnormalitas larva ikan nila pada perlakuan $\mathrm{B}$ $\left(40^{\circ} \mathrm{C}\right)$ dan $\mathrm{D}\left(42^{\circ} \mathrm{C}\right)$ berbeda nyata $(\mathrm{p}<0,05)$ dengan perlakuan $\mathrm{C}\left(41^{\circ} \mathrm{C}\right)$ dan $\mathrm{A}\left(28^{\circ} \mathrm{C}\right)$, sedangkan perlakuan $\mathrm{C}\left(41^{\circ} \mathrm{C}\right)$ berbeda nyata $(\mathrm{p}<0,05)$ dengan perlakuan $\mathrm{A}\left(28^{\circ} \mathrm{C}\right)$.

Kualitas air yang diukur adalah suhu, $\mathrm{pH}$ dan oksigen terlarut. Suhu air inkubasi berkisar antara $26-28^{\circ} \mathrm{C}, \mathrm{pH} 7$ dan oksigen terlarut sebesar $8 \mathrm{ppm}$.

Daya fertilisasi sangat ditentukan oleh kualitas telur, sperma, media dan penanganan manusia (Masithah dan Alamsjah, 2002 dalam Handayani, 2007). Rata - rata persentase fertilisasi selama penelitian yaitu sebesar 98,5 persen. Hal ini menunjukkan kualitas dan jumlah sperma cukup baik untuk membuahi telur. Telur yang terfertilisasi terlihat dari warna telur yang bening. Hal tersebut sesuai dengan pernyataan Rustidja (2004) bahwa telur yang perkembangannya sehat adalah berwarna transparan dan bersih, sehingga mudah dibedakan dengan telur yang mati.

Hasil penelitian daya tetas larva ikan nila menunjukkan bahwa perlakuan tertinggi terjadi pada perlakuan dengan kejutan suhu $40^{\circ} \mathrm{C}$, hal ini sesuai dengan penelitian Pudjirahaju dkk. (2006) bahwa suhu kejutan panas yang tepat adalah $40^{\circ} \mathrm{C}$. Diduga suhu tersebut masih dalam kisaran perkembangan telur sehingga dapat menghasilkan sigot diploid. Kejutan suhu juga diduga dapat mengakibatkan kerusakan pada benang-benang spindel yang terbentuk saat proses pembelahan sel dalam telur. Dugaan ini didukung oleh pendapat Gervai et al. (1980) dalam Mukti (2005) yang menyatakan bahwa kejutan suhu dan tekanan dapat merusak mikrotubulus yang membentuk spindel selama pembelahan.

Kejutan suhu panas diberikan setelah terjadinya peloncatan polar body II, di mana saat sigot diploid atau sebelum mengalami mitosis. Kejutan suhu panas diberikan dengan tujuan untuk mencegah pembelahan sel secara mitosis pada sigot diploid setelah terjadi penggandaan kromosom, oleh karena itu kromosom yang terbentuk setelah perlakuan kejutan panas ini menjadi 4n (Rustidja, 1991 dalam Mukti 2005). Namun, saat diberi kejutan ada bagian dari sepasang kromosom homolog tidak bergerak memisahkan diri pada 
waktu mitosis. Satu gamet menerima dua jenis kromosom yang sama dan gamet lainnya tidak mendapatkan kromosom. Jika salah satu gamet yang menyimpang bersatu dengan gamet normal pada waktu pembuahan, maka keturunannya akan memiliki jumlah kromosom yang abnormal. Bila organisme tersebut mampu bertahan hidup, organisme tersebut akan memperlihatkan sejumlah gejala yang disebabkan oleh abnormalnya jumlah gen yang terletak pada kromosom tambahan atau kromosom yang hilang (Campbell, dkk., 2002).

Hasil penelitian abnormalitas larva ikan nila menunjukkan bahwa abnormalitas tertinggi terjadi pada perlakuan yang diberi kejutan suhu $40^{\circ} \mathrm{C}$. Abnormalitas terjadi diduga saat pemberian kejutan suhu panas ada sebagian telur yang belum bisa mengembalikan jumlah kromosom yang berkurang pada saat proses perkembangan telur yang diinginkan, yaitu menghasilkan sigot diploid (2n) dan telah mengalami modifikasi kromosom, sehingga sebagian telur yang menetas pada tiap perlakuan ada yang menghasilkan larva abnormal. Dugaan ini didukung oleh pendapat Hasanuddin (1995) dalam Pudjirahaju dkk. (2006) yang menyatakan bahwa individu haploid akan menjadi abnormal.

Selain itu suhu terlalu tinggi dapat mengganggu aktivitas enzim penetasan pada telur dan mengakibatkan pengerasan pada chorion, sehingga menghambat proses penetasan telur dan dapat mengakibatkan terjadinya keabnormalitasan (cacat) pada larva ikan yang dihasilkan (Mukti, 2005). Biedwell et al. (1985) dalam Mukti (2005) mengemukakan, larva ikan yang cacat dapat disebabkan oleh lapisan terluar dari telur (chorion) yang mengalami pengerasan, sehingga embrio akan sulit untuk keluar. Setelah chorion dapat dipecahkan, maka embrio akan keluar dalam keadaan tubuh cacat.

Parameter kualitas air berperan dalam proses pemijahan dan penetasan telur. Kualitas air media inkubasi seperti suhu, $\mathrm{pH}$ dan oksigen terlarut berada pada kondisi optimal. Hasil pengukuran suhu air inkubasi selama penelitian berkisar antara $26-28^{\circ} \mathrm{C}$, pH 7 dan oksigen terlarut 8 ppm. Hal yang sama dikemukakan oleh Khairuman dan Amri (2003) bahwa suhu optimal untuk pemijahan ikan nila berkisar antara $25-30^{\circ} \mathrm{C}$. Faktor lain yang berpengaruh terhadap penetasan telur adalah $\mathrm{pH}$ dan oksigen terlarut. Kisaran $\mathrm{pH}$ optimal untuk penetasan adalah 6,2 - 7,8 (Yustina dan Darmawati, 2003). Oksigen terlarut dibutuhkan dalam proses metabolisme embrio di dalam telur.
Hasil pengukuran oksigen terlarut selama penelitian sebesar 8 ppm.

\section{Kesimpulan}

Kejutan suhu panas memberikan pengaruh terhadap daya tetas dan abnormalitas larva ikan nila, sedangkan lama waktu setelah pembuahan tidak memberikan pengaruh terhadap daya tetas dan abnormalitas larva ikan nila, kejutan suhu panas dan lama waktu setelah pembuahan yang menghasilkan persentase daya tetas dan abnormalitas tertinggi terdapat pada perlakuan suhu $40^{\circ} \mathrm{C}$.

Penggunan kejutan suhu panas dengan suhu $40^{\circ} \mathrm{C}$ dapat menghasilkan daya tetas dan abnormalitas tertinggi, namun masih perlu dilakukan penelitian lebih lanjut terhadap pertumbuhan larva ikan nila setelah proses kejutan suhu.

\section{Daftar Pustaka}

Campbell, N. A., J. B. Reece dan L. G. Mitchell. 2002. Biologi. Edisi Kelima Jilid I. Erlangga. Jakarta. hal. 289-290.

Handayani, S. 2007. Respon Pemberian Kelenjar Hipofisa Ayam Layer Afkir terhadap Waktu Latensi, Derajat Fertilisasi dan Derajat Penetasan Telur Ikan Komet (Carassius auratus auratus). Skripsi. Budidaya Perairan Fakultas Kedokteran Hewan. Universitas Airlangga. 55 hal.

Herbst, E. C. 2002. Induction of Tetraploidy Zebrafish (Danio rerio) and Nile Tilapia (Oreochromis niloticus). Thesis. University of North Carolina at Charlotte. $139 \mathrm{p}$.

Khairuman dan Amri. 2003. Budidaya Ikan Nila Secara Intensif. Agromedia Pustaka. Jakarta. hal. 22

Mukti, A. T. 1999. Sex Manipulation-Hibridization Progames. Program Pasca Sarjana. Universitas Brawijaya. Malang. 15 hal.

Mukti, A. T. 2005. Perbedaan Keberhasilan Tingkat Poliploidisasi Ikan Mas (Cyprinus carpio Linn.) melalui Kejutan Panas. http://journal.discoveryindonesia.com. 23 Juni 2008. 6 hal.

Mukti, A. T., Rustidja, S. B. Sumitro dan M. S. Djati. 2001. Poliploidisasi Ikan Mas (Cyprinus carpio L.). Jurnal Ilmu-Ilmu Hayati Biosain, 1(1):111-123.

Pudjirahaju, A., K. Bungas dan K. Yuliany. 2006. Pengaruh Perbedaan Suhu Kejutan Panas terhadap Keberhasilan Gynogenesis pada Ikan Mas (Cyprinus carpio L.). Journal of Tropic 
Fisheries, 1(2):126-131.

Risnandar, D. 2001. Pengaruh Umur Zigot pada Saat Kejutan Panas terhadap Keberhasilan Triploidisasi serta Kelangsungan Hidup Embrio dan Larva Ikan Jambal Siam (Pangasius hypopthalmus). Skripsi. Budidaya Perairan. Fakultas Perikanan dan Kelautan. Institut Pertanian Bogor. Bogor. 60 hal.

Rustidja. 2004. Pemijahan Buatan Ikan-Ikan Daerah Tropis. Bahtera Press. Malang. hal. 91.

Shelton W. 2006. Artificial Propagation of Nile Tilapia for Chromosome Manipulation. Dept. of Zoology. University of Oklahoma, United States. pp. 69-70.

Suzu, S., Fujimoto, T., Kimura, S., Yamaha, E and Arai K. 2006. Drastic Mortality in Tetraploid Induction Results from the Elevation if Ploidy Masu Salmon Onchorhyncus masou. Aquaculture, 252:147-160.
Wardoyo, S. E. 2005. Peningkatan Produktivitas Ikan Nila, Oreochromis niloticus di Indonesia. http://www.dkp.go.id/. 17 Juni 2008. 1 hal.

Wirawan, I. 2005. Efek Pemaparan Copper Sulfat (CuSO4) terhadap Daya Tetas Telur, Perubahan Histopatologik Insang dan Abnormalitas Larva Ikan Zebra (Brachydanio rerio). Tesis. Program Pasca Sarjana. Universitas Airlangga. Surabaya. 77 hal.

Yustina, A. dan Darmawati. 2003. Daya Tetas dan Laju Pertumbuhan Larva Ikan Hias Betta Splendens di Habitat Buatan. Jurnal Natur Indonesia 5(2):129-132. 